\title{
SOSYAL VE GELENEKSEL BOYUTLARIYLA BURSA DAĞ YÖRESİ CUMA CAMİLERİ ${ }^{1}$
}

\author{
Yrd. Doç. Dr. Alaattin DİKMEN \\ Celal Bayar Üniversitesi, Fen Edebiyat Fakültesi, \\ Sosyoloji Bölümü
}

ÖZ

Uludağ'ın güney yamaçlarında bulunan Büyükorhan, Harmancık, Keles ve Orhaneli Bursa'ya bağll ilçelerdir ve Bursa ilinin "Dă̆ Yöresi" olarak adlandırılmaktadır. Bu ilçelerde ve köylerinde yegâne ibadet mekânı olan camiler ilk dönemlerindeki gibi, gündelik hayatın önemli bir parçasını oluşturmaktadırlar.

Dă̆ Yöresinde yakın zamana kadar, birçok köy cuma ve bayram namazları için bir araya gelerek, ibadetlerini geniş katılımlarla gerçekleştirmekteydiler. Bütün İslam beldelerinde olduğu gibi Dăg Yöresinde de bu ibadetlerin ifa edildiği mekânlara, 'cami', 'cami yeri', 'mescit' gibi kavramlar kullanılmakla birlikte en fazla kabul göreni "Cuma Camisi" olmaktadır.

Cemaat halinde yapılan ibadetlerin yegâne yeri olması hasebiyle camiler, İslam tarihi boyunca sosyal yönü güçlü mekânlar olagelmişlerdir. Fonksiyonel olarak bazı sosyal ve kültürel değişmelere uğramış olmalarına rağmen Dă̆ Yöresinde camiler bu özelliklerini halen sürdürmektedirler. Birçoğu yok olsa da, kuruluşundan itibaren bütün fonksiyonelliğini sürdüren Cuma Camileri halen bulunmaktadır.

Anahtar Kelimeler: Değişim, Cuma Camii, Cuma Yeri, Gelenek, Bursa Dağ Yöresi, Namazgâh.

\section{FRIDAY MOSQUES IN MOUNTAINOUS REGION IN BURSA}

\begin{abstract}
Buyukorhan, Harmanclk, Keles and Orhaneli, located on the southern slopes of the Uludag, are districts also called 'Mountainous Region of Bursa province'. The mosques which are the only place of worship in these towns and villages have been setting up the social aspect of everyday life as it was in its very early times.

In the entire region, it is known that many villages come together for Friday prayers and Eid prayers twice a year and these worships are performed with a high level of participation, until recently. As in all Islamic towns, in these districts, places where worship is carried out are named with words and concepts such as 'mosque', 'place to come together' and 'masjid', but rather as 'Friday Mosque'.
\end{abstract}

\footnotetext{
${ }^{1} \mathrm{Bu}$ makale daha çok katılımcı gözlem yöntemiyle ulaşılan verilerden oluşmaktadır. Makalede adı geçen mekân ve yerlerin tamamına gidilmiştir. Fotoğraflar da araştırıcı tarafından çekilmiştir.
} 
Mosques, throughout Islamic history, have been socially powerful places owing to the fact that these buildings serve as the only places for worships performed in congregation.

Although they undergone some social and cultural changes, mosques in Mountainous region maintain this characteristics. Despite the fact that many have lost their functionality, there still exist Friday Mosques maintaining all their functions.

Keywords: Change, Friday Mosque, Place for Friday prayer, tradition, Mountainous Region in Bursa, Namazgah

\section{GIRIŞ}

Medine'de İslam kurumsal bir yapıya bürünmeye başladığında, ibadetler alanında da belli başıı uygulamalar ve yapılanmalar ortaya çıkmaya başlamıştır. Mesela Medine'de ilk inşa edilen ve bir tarafıyla ibadethane olan Mescid-i Nebevî'den ayrı, bazı kaynaklara göre Hz. Peygamberin izni alınarak on sekiz mescidin daha inşa edildiği anlatılmaktadır. $\mathrm{Bu}$ mescitlerde vakit namazları kılınırken Cuma namazı sadece Mescid-i Nebevî'de kılınmaktadır. İslam'ın ilk döneminde başlayan bu uygulama sonraki dönemlerde gelenek haline gelmiş, Osmanlının belli bir dönemine kadar da imkânlar ölçüsünde devam etmiştir.

Osmanlı Müslüman tebaasının yaşadığı büyük yerleşim yerlerinde Cuma namazları genellikle tek camide kılınmaya çalışılmış bu amaçla da şehirlerde "Cuma camileri” inşa edilmiştir. Yakın yerleşim yerlerinden, köy ve beldelerden, çok sayıda insanın Cuma namazını kılmak amacıyla bu tür camilere geldiği bilinmektedir. Köy ve kasaba türü yerleşim yerlerinde de benzer uygulamalar olmuştur. Günümüzde bile halen bu uygulamanın izlerine rastlanmakta, hatta uygulamanın bazı yerleşim birimlerine yaşatıldığ bilinmektedir. $\mathrm{Bu}$ yerleşim alanlarından biri si de Bursa ilinin Uludağ yamaçlarında kurulu bulunan, Bursa Dağ Yöresi diye de adlandırılan dört ilçe ve köyleridir.

\section{Cami, Cuma Kavramları}

“Arapça 'cem' kökünden türeyen, 'toplayan, bir araya getiren' anlamındaki 'cami' kelimesi, başlangıçta sadece cuma namazı kılınan büyük mescitler için kullanılan 'el-mescidü'1-câmi' (cemaati toplayan mescid) tamlamasının kısaltılmış şeklidir.” (Önkal,1993: 46) 'Mescid’ ise, Arapça’da 'eğilmek, tevazu ile alnı yere koymak' mânasına gelen sücûd kökünden 'secde edilen yer' anlamında bir mekân ismidir. (Önkal,1993:46) Bu kelime zamanla, namaz kılınan birçok mabet türünü anlatmak için kullanılır olmuştur.

Hicrî IV. (Milâdî X.yy) yüzyılın başlarında 'cami' kelimesi tek başına kullanılmaya başlanmıştır. Daha sonraki dönemlerde, Müslümanların karşılaştığı kültürler ve coğrafyalar genişledikçe bu kavramın tanımladığ i içerik yeni anlamlara zenginleştirilmiştir. İçinde Cuma namazı kılınan ve hatibin hutbe okuması için minber bulunan mescitlere cami; minberi bulunmayan, cuma namazı kılınmayan ve camiye göre daha küçük olan mâbedlere ise mescid 
denilmiştir. ${ }^{2} \mathrm{Bu}$ yerler daha özel bir isimle de anılarak 'namaz kılınan yer' anlamında Musallâ kavramıyla tanımlanmıştır. Kitleler halinde katılımın olduğu ve sosyal yönü daha ağır basan namaz ibadeti bu musallalarda yapılmış, özellikle Cuma ve bayram namazları buralarda kilınmıştır. Musalla, Salat kökünden türetilmiş bir mekân ismidir ve "Namazgâh" olarak dilimize çevrilmiş̧ir. Hz. Peygamber devrinde, Medine'de, Ramazan ve Kurban bayram namazlarının kılındığı yer için kullanılan bir 1stılahtır.(İbn Sa'd, 2001: 214, Taberi,1968: 396, Wensinek, VIII: 673)

Beldelerin görünür yerlerinde, geniş mekânlarda ve daha çok da yol güzergâhlarında inşa edilen, benzer fonksiyonlarından dolay1 zaman zaman Musalla adı verilen diğer bir mescit türü de Namazgâhlardır. Osmanlının ilk dönemlerinden itibaren bu tür mabetlere rastlanılmaktadır. Bunlardan ilki günümüzde halen kullanılmakta olan ve Ramazan aylarında teravih namazları için ibadete açık tutulan Bursa Namazgâhıdır. ${ }^{3}$ Bu ibadet mekânının kullanımı ve özellikleriyle ilgili olarak kaynaklarda şöyle bir açıklama yer almaktadır:

"Bursa fethinde salât-ı Cum'a ve 'yydeyn edâ olmak içün binâ olunmuştur. Etrafi kârgir divardır. Beş kapusı vardır. Taşdan bir mescit ve mihrâp ve bir kürsî vardır. Oniki bin asker almağa mütehammil bir musallâdur. Gâhi yaz günlerinde salât-ı 'ideyn eda olunur. Rahmet duasina anda cem' olurlar. Gâyetde rûhâniyetlü ve sefâ-bahşa bir mahalle-i mübârekedir. Mescid-i Aksâ resmindedir. Bursa'da Câmi-i Kebir (Ulucâmi) binâ olmazdan evvel salât¿Cum'a ve salât-l 'iydeyn anda eda olunurdu." (Armağan,1998: 82)

Osmanlı döneminde mescitlerle ilgili diğer önemli bir tasnif türü ise bu mekânların yapılış özelliklerinden ziyade yaptıran şahsa göre tasnife tabi tutulmasıdır. Bu tasnifte sosyal ve kültürel kabuller önemli olmuştur. Buna göre; padişahlar tarafından inşa ettirilen büyük camilere "Selâtin Camileri", vezirler ve diğer devlet ricali tarafından yaptırılan orta büyüklükteki camilere banisinin adına izafet edilerek sadece "..... Cami”, ebat olarak küçük ve daha sade yap1 malzemesi kullanımlı olanlara da "Mescid" denilmiştir. Genellikle mescitlerde Cuma namazı kılınmamıştır. Bir mescitte Cuma namazı kılınması

2 Müslümanların ibadet mekanı olan Cami, mescit, mabet gibi kavramlar, tarihçe, çeşitleri, fonksiyonları, kuruluş amaçları, sanat ve tarihi boyutlarıyla ilgili olarak daha geniş ve kapsayıcı bilgi ve konuyla ilgili geniş bir literatür için bkz. "Cami” maddesi, TDV İslam Ansiklopedisi, C.VII., ss.46-87; Kasım Kufralı, "Cami” maddesi, İslam Ansiklopedisi, M.E.G..S.B., C.3, İst M.E.Basımevi,1988, s.227-228; Mustafa Agırman, "Hz. Peygamber'in Mescidde Yaptıgı Sohbetler", Atatürk Üniversitesi İlâhiyat Fakültesi Dergisi, sayı: 27, Erzurum, 2000, s.104

3 Konuyla ilgili geniş bilgi için; Alaattin Dikmen, "Semaya Açık Namazgahlar", Bursa'nın Tarihi Mahalleleri II, Bursa Büyük Şehir Belediyesi Yay., Bursa 2011, s.188191,. Zafer Ünver, "Namazgahlar”, a.g.e., s.184-187. Bedri Mermutlu, "Kurtoğlu, Namazgah”, a.g.e., s.176-182. Hüdavendigâr Akmaydalı, Vakıflar Dergisi, Sayı 23, Yıl 1994, s.123-124. 
zaruri hale gelmişse, bunun için yerel yetkili birimler tarafından "bu mescitte Cuma namazı kılınabilir”' diye 'berat' ve 'izin' verilmesi gerekli görülmüştür. ${ }^{4}$

\section{Tarihi Boyut}

Hz. Peygamber zamanında mescid, sadece beş vakit namaz ve Cuma namazının kılındı̆̆ı bir namazgâh değil, bir eğitim/öğretim kurumu, bir muhakeme ve mahkeme mekân1, yönetimin merkezi, askerin karargâhı, kısacası toplumla ilgili dinî ve dünyevî bütün işlerin görüldügü bir merkezdi.(Ağırman, 2000: 103)

Diğer taraftan Hz. Peygamber döneminde, özellikle Cuma namazlarının geniş ve çoklu katılımlarla gerçekleştirildiği bilinmektedir. Çünkü Medîne'de, Mescid-i Nebevî'den ayrı dokuz, diğer bir kaynağa göre Peygamberin izni ile on sekiz mescidin daha bulunduğu, buralarda vakit namazlarının kılınmasına rağmen Cuma namazının sadece Mescid-i Nebevî’de kılındığı kaynaklarda belirtilmektedir. ${ }^{5}$ (Dursun, 1990: 282) İslam tarihindeki bu gelenek, Osmanlının belli bir dönemine kadar, imkânlar ölçüsünde devam etmiş, Cuma namazları genellikle büyük yerleşim yerlerinde tek camide kılınmaya çalışılmış ve bu amaçla şehirlerde "Cuma camileri" inşa edilmiştir. Yakın yerleşim yerlerinden, köy ve beldelerden, çok sayıda insanın Cuma namazını kılmak amacıyla bu tür camilere geldiği bilinmektedir. (Şahinalp, 2005: 75)

Medine'de Mescid-i Nebevinin dışında geniş katılımlı namaz ibadetlerinin yapıldığı çeşitli mekanların olduğu kaynaklarda anlatılmaktadır. “Hz. Peygamber Medine'ye yerleştikten sonra, ilk defa hicretin 2. yılı Şevval ayının ilk gününde Ramazan bayramı, aynı yılın Zilhicce ayının onuncu günü de Kurban bayram namazları Musallâ'da kılınmıştır. Necâşî tarafindan. Zübeyr b. el-Avvâm'a armağan edilen mizrak her bayram namazında, Mualla'ya götürülerek, kıble istikametine dikilirdi." 6

\section{Dağ Yöresinde Cuma Camilerinin Sosyal ve Kültürel Arka Planı}

Köy ve mahalle, Osmanlı iskân hayatının ve sosyal yapısının en temel unsuru olmuştur. Köyü ve mahalleyi oluşturan bireyler birbirlerini tanımakta, davranışlarını kontrol etmekte ve belirli bir sosyal dayanışma sergilemektedirler. (Gümüşçü, 2002: 89-90, Bayartan, 2005: 95). Bundan dolay1 buralarda sosyal birçok görev sağlıklı bir şekilde yerine getirilmiştir. Türkiye'de şehirlere göçün yoğun olarak yaşandığg 1980'li y1llara kadar köyler bu fonksiyonlarını başarıyla yerine getirmişlerdir. Son 30 yılda nüfusun \% 70'lik bir kısmının köylerden şehirlere göç etmesiyle sosyo-kültürel hayat ve onu

\footnotetext{
${ }^{4}$ Ağırman, a.g.m., s.106; Bu tür ayrımlar için ayrıca bkz.; Semavi Eyice, Cami Mimari Tarih, TDV İslam Ansiklopedisi, , C.7, s.56-87, İst. 1993

5 A.g.m.,s.104; Ayrıca, ilk dönem Cuma Camileri için bkz.; Mehmed İpşirli, "Cuma Selamlığı”, TDV İslam Ansiklopedisi, , C.8, s.90, İst. 1993

${ }^{6}$ İbn Sa'd, age, I, 214; AJ. Wensinek, î. A. VIII, 673; Ayrıca daha geniş bilgi için bkz., Bütün Yönleriyle Asr-ı Saadette İslam, Edt. Vecdi Akyüz, C.3, Beyan Yay., İst., ?, s.211-256.
} 
şekillendiren coğrafi/fiziki yapılarda da ciddi değişmeler yaşanmıştır. (Bilici, 2012: 18)

Köyler genel olarak coğrafi/fiziki şartlarla birlikte, inanç değerlerinin belirleyici unsurlarıyla şekillenmektedir. Mahalle ve köylerin cami/mescit gibi bir ibadethane etrafinda teşekkül etmesi İslam geleneğinin bir yansımasıdır. (Yediyıldız,1988: 298) Dini ve geleneksel davranış örüntülerinin hâkim unsur olduğu köy toplumlarında cami merkezi bir konumdadır. (Ergenç,1995: 50) Bundan dolayı da sosyal, kültürel ve geleneksel olayların çoğu cami etrafında şekillenmektedir. (Dikmen, 2011: 45, Kuban,1953: 54,66-67)

"Cami eksenli gelişen bu durumla ilgili olarak şunlar söylenebilir:

1- Yerleşim birimindeki insanlar belli aralıklarla bir araya gelir, tanışır, dinî ve dünyevî işlerini görür, aynı zamanda merkezi otoritenin tarzını insanlara aktarır,

2- İnsanların hayatını yönlendirmek suretiyle, maddi ve kültürel alanlarda dolaylı bir "üretim kontrolü”nü gerçekleştirmenin etkili bir aracı olur,

3- Toplum içinde kaynaşmayı temin ederek, köylü/mahalleli fikri etrafında toplanarak, gerektiği zaman "ortak kararlar" almayı sağlayan mekân olarak ayrı bir önem kazanmaktadır.” Özdeğer,1988:120)

4- Çoğu yerleşim yeri için yerleşim önceliğini belirleyen yegâne etkenin mabet/cami olduğu rahatlıkla söylenebilir. Dolayısıyla, sosyal hayat bu mabet etrafında gelişmekte ve şekillenmektedir.

$\mathrm{Bu}$ ve benzer sonuçlara bakarak mahallenin/köyün idare merkezinin cami olduğu söylenebilir. (Bayartan, 2005: 99) Bu boyutuyla camilerin sosyal, kültürel ve idari olarak birçok önemli fonksiyonu bulunmaktadır. ${ }^{7}$

Türkiye genelinde camiler cemaat, kadro, mimari durumları ve yapılan ibadetlerin sıklık durumlarına göre genel bir sınıflandırmaya tabi tutulmuştur. $\mathrm{Bu}$ çalışmalarda sadece bayram namazı ve Cuma namazlarının kılındığı camilere yer verilse de kesin bir envanter çalışması yapılmış değildir. (Onay, 2007: 77-121) Türkiye coğrafyasında var olan birçok cami ve mescitlerle ilgili veriler Diyanet İşleri Başkanlığınca yürütülen çalışmalarla kayıt altına alınmaktadır. Ancak Bursa Dağ Yöresinde var olan Cuma camileri ya da Cuma mescitleri henüz bu kayıtlara geçirilmemiştir. Bu camiler/mescitler işlerliğini ve görevli meselesini ya yerel imkânlarla sürdürmekte ya da bir bir kapanmakta ve yok olmaktadır.

\section{Bursa Dağ Yöresi Cuma Camileri}

Bursa'ya bağlı Büyükorhan, Harmancık, Keles ve Orhaneli ilçeleri, Güney Marmara ile Ege Bölgesinin kesişim çizgisinde yer almaktadırlar. Bu ilçeler ve köyleri Uludağ'ın daha engebeli olan güney yamaçlarında konumlandığı için Bursa ilinin "Dağ Yöresi" olarak adlandırılmaktadır. Dă̆ Yöresi yerleşim yerlerinin ayırt edici bir özelliği yöre insanının kendini

\footnotetext{
${ }^{7}$ Bayartan, agm., s. 100; Ayrıca camilerin bir kıraathane işlevi de gördüğüne dair bkz., Osman Nuri Ergin, Türkiyede Şehirciliğin Tarihi İnkişafi, İst., 1936, s.104.
} 
Türkmen, Yörük, Karakeçili/Kızılkeçili Yörüğü ve Manav gibi isimlerle tanıtmasıdır. Bu tanımlamalarından dolayı yöre halkının bölgeye yerleşen ilk Türk boylarından olduğu genel kabul görmektedir. (Cemiloğlu, 2005:39-40, Cemiloğlu,2002:388, Dinçel,2003:67, Dikmen.2012:25-27)

Dağ Yöresi'nin tamamında, birden fazla köyün bir araya gelerek sadece cuma ve bayram namazlarını kıldıkları, yerel olarak "cami yeri” daha çok da “Cuma Camisi” diye adlandırılan mekânların varlığı bilinmektedir. İslam tarihinin ilk dönemlerinden günümüze kadar değişik Müslüman coğrafyalarında görülmüş olan bu geleneksel uygulama Dağ Yöresinde, son çeyrek asra kadar birçok camide uygulanan bir gelenek iken günümüzde sadece iki Cuma camisinde devam ettirilmektedir.

Çevre köylerde yaşayanların haftada bir kez de olsa kalabalık gruplar halinde toplanarak, sosyal dayanışmanın önemli bir göstergesinin zeminini oluşturdukları bu uygulama son yıllarda, terk edilse de bir zamanlar yörede birçok cami ya da uygun mekânda, kalabalık cemaatle kılınan Cuma ve bayram namazlarının eda edildiğini hatırlayan insanlar bulunmaktadır. Bu insanlar, çok sayıda yerleşim yeri sakininin bir araya gelerek ibadet ettiğini, katılımın mevsimine göre çok geniş olduğunu, bazen yemekli yapıldığını ve ibadetlerin bir şölen havasında eda edildiğini anlatmakta, o günleri “özel günler” olarak yad etmektedirler. ${ }^{8}$

\section{A. Yapı Özelliklerine Göre Cuma Camileri}

İnsanlar yaz kış demeden cuma günleri erken sayılabilecek saatlerde bu mekânlarda toplanmışlardır. Cami ve müştemilatı genellikle caminin giriş bölümünde ve çevresinde 1sınma, oturma, dinlenme, abdest alma gibi temel ihtiyaçları karşılayacak şekilde yapılmıştır. Hatta yemek hazırlama ve dağıtımını sağlamak için bile mekânlar oluşturulmuştur. Bu camiler Dağ Yöresi gibi kırsal bölgeler için sosyalleşmenin yanı sıra, İslam tarihinin ilk dönemlerinden itibaren varlık alanına çıkmış kadim bir geleneğin en yoğun yaşandığı mekânlar olmuştur.

"Cuma Yeri”, "Cuma Cami” adı verilen bu camiler var olma durumuna göre şöyle sıralanabilir:

- Yarım asır öncesine kadar varlığı bilinen ama günümüzde kalıntıları bile kalmayıp sadece yaşlı nesillerin yerini hatırladığı alanlar. $^{9}$

- İbadet icrası yapılmadığı için zamanla yıkılıp gitmiş ve sadece kalıntıları kalmış olanlar. ${ }^{10}$

\footnotetext{
${ }^{8}$ Keles Kozağacı mevkii denilen ve 8-9 köyün bulunduğu bölgede Davutlar Köyü’nün alt kısmındaki düzlükte, Büyükorhan Danacılar Köyü’nde olduğu gibi.

${ }^{9}$ Büyükorhan Danacılar köyü; Keles'e bağlı dokuz kadar köyün yer aldığı Kozağacı mevkiinde olduğu gibi.

${ }^{10}$ İshaklar köyü (yakınlarında metruk bir çamaşırhanenin de yer aldığı mevkie yakın bir alan) Harmancık, Yine Harmancık ilçesine bağlı Dedebalı, Ilıcaksu, Dutluca köylerinin orta noktası sayılabilecek olan bir mevkide yer alan Cuma Yeri gibi. Günümüzde bu alanda yılda bir kez yemekli olarak düzenlenen geniş katılımlı köy hayrı yapılmaktadır.
} 
- Yapısı sağlam olduğu halde ibadet yapılmadığı için kendi haline terk edilmiş olanlar. ${ }^{11}$

- Kurulduğu günden bu yana işlevini sürdürmüş ve günümüzde de hala fonksiyonunu icra etmekte olanlar. ${ }^{12}$

B. Varlığını Sürdüren Ama İşlevi Olmayan Cuma Camileri

Sayıları her ne olursa olsun önceleri çok yaygın olsalar da ilk iki grupta yer alan camilerden söz etmek yersizdir. Çünkü sadece yerleri bilinmektedir. Son iki grupta yer alan camilere ise, yörede rastlamak mümkündür. Mesela yapısı sağlam olduğu halde ibadet yapılmadığı için kendi haline terk edilmiş olan Harmancık ilçesine bağlı Çatalsöğ̈̈t köyündeki Cuma Cami yapı özelliklerini hala korumaktadır. Ne var ki yapısı, malzemesi ve tarzıyla orijinal bir taş yapı örneği olarak düşünülebilecek olan bu Cuma Camisi son yıllarda cemaatsiz kalmıştır. Yani bu cami sosyal ilişkilerin yoğun olarak kurulduğu ve geliştirildiği bir mekân olma özelliğini yitirmiştir. Çünkü yakın çevrede bulunan her mahalle ve köyün sakinleri cuma namazını kendi camisinde kılmak istemektedir. Günümüzde bu cami kaderine terk edilmiş, metruk bir vaziyettedir.

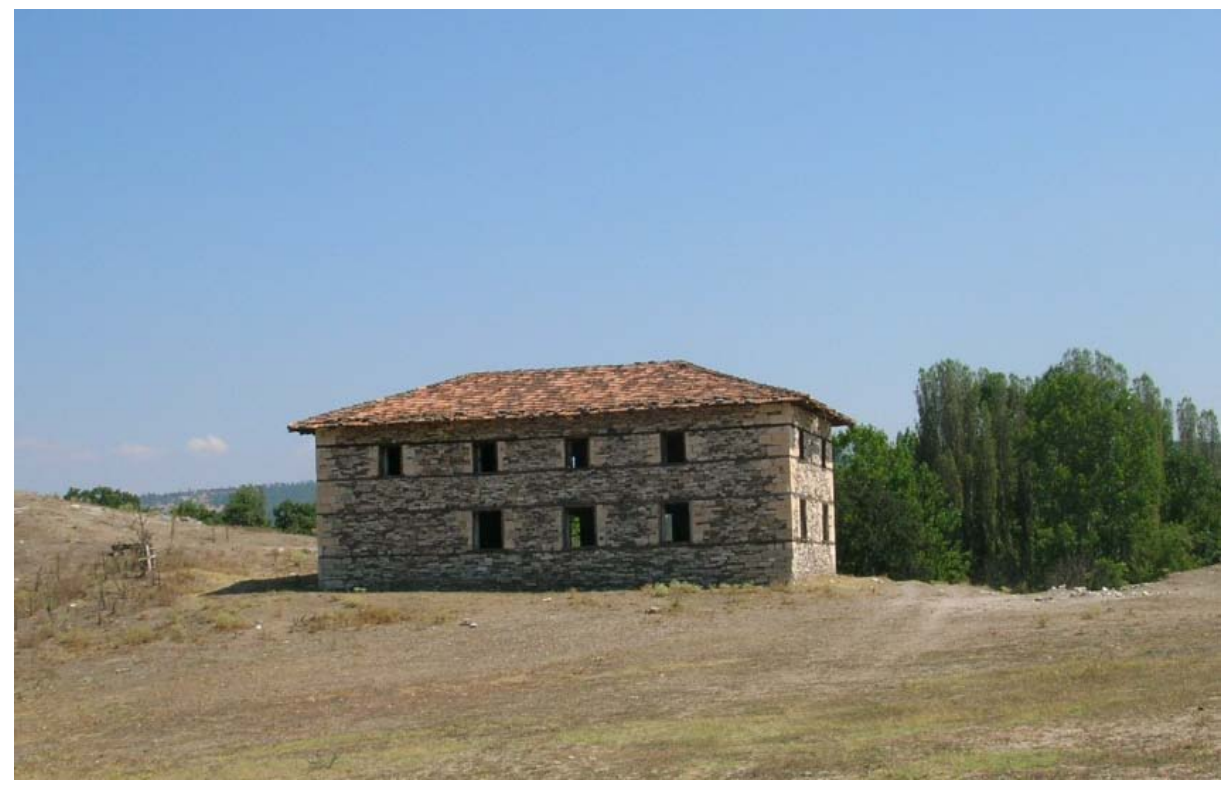

Yapı Özelliklerini Hâlâ Koruyan Çatalsöğüt Köyü Cuma Camisi

${ }^{11}$ Harmancık ilçesinin Çatalsöğüt Köyü ile bu köye bağlı Doğancılar ve Demirciler mahallelerinin ortak bir noktasında hala metruk halde duran Cuma Cami gibi.

12 Büyükorhan ilçesine yakın bir yerde her hafta Cuma günleri yörenin en geniş katılımlı hayvan pazarı olarak kurulan ve Cuma Pazarı denilen yerde bulunan Cuma Camii ile Harmancık ilçesine bağlı Nalbant köyü yakınındaki Cuma Camii örneği gibi. 


\section{C. İşlevini Sürdüren Cuma Camileri}

Yörede varlığını sürdürmenin yanı sıra işlevini de henüz yitirmemiş olan Cuma camileri bulunmaktadır. Bu camiler ilk kurulduğundan bu yana, her hafta Cuma günleri insanların bir araya gelmelerinde, sosyalleşmelerinde, sosyal ve kültürel hayata katılımlarında hatırı sayılır bir işlevler üstlenmişlerdir. $\mathrm{Bu}$ nedenle Cuma camileri, özellikle dar toplumlarda, sosyal ve kültürel açılardan önemli hizmetler ifa etmektedirler.

\section{Nalbant Köyü Cuma Cami}

Bu camilerden en önemlisi Harmancık ilçesine bağlı Nalbant köyünde yer alan Cuma camisidir. Cami kurulduğu günden bu yana Cuma Camisi olarak fonksiyonunu icra etmektedir. Yapımı oldukça sade olup, taş/ahşap karışımı malzemelerden oluşmaktadır. Ayrıca antik kalıntılara ait bazı mermer elemanların yapıda kullanılmış olması bu camiye ayrı bir özellik katmaktadır.

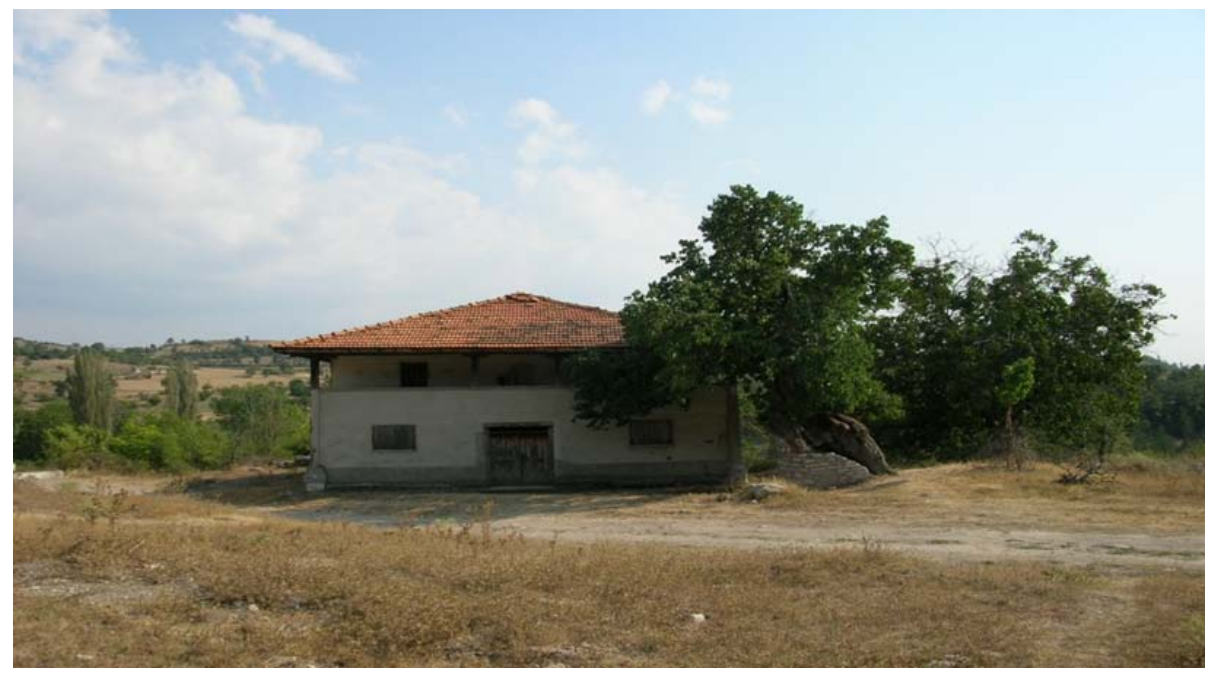

Günümüzde de faaliyette olan Nalbant Köyü Cuma Camii/Harmancık

Diğer taraftan Nalbant köyünde iki ayrı cami daha bulunmaktadır ki bu iki camiyi başka camilerden ayıran ve özellikli kılan ise her ikisinde de minber (camilerde Cuma ve Bayram namazlarında İmam-Hatiplerin cemaate hitap ettikleri merdivenle çıkılan yer) olmamasıdır. Bu camilerin ilk yapıldığı günden itibaren minbersiz olarak inşa edilmiş olması iki caminin cemaatinin Cuma ve Bayram günleri köylerinde üçüncü bir camii olarak bulunan ve sadece Cuma ve bayram namazlarının kılındığı Cuma Camisinde toplanmalarını sağlamaya yönelik olmasıdır. Bu iki camiye minber yapılması halinde Cuma Cami işlevsiz kalacağından köy sakinleri iki camiye de minber yapmamışlardır. Çünkü iki mahalleli ve iki camili köyde Cuma Cami onları haftada bir kez olsun bir araya getirmektedir. $\mathrm{Bu}$ ise onlara sosyal dayanışma, kaynaşma ve paylaşmanın zeminini hazırlamaktadır. 


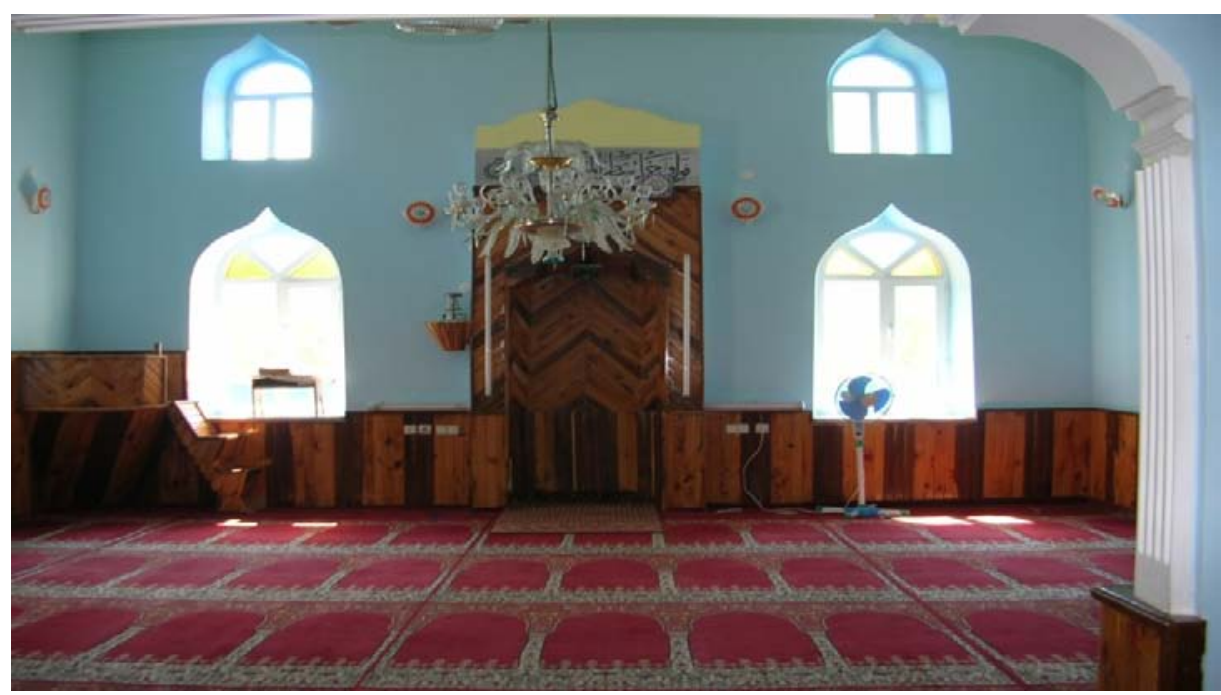

Nalbant Köyünde Minbersiz Köy Cami/Harmancık

Diğer taraftan, iki ayrı köy ve mahallenin bu camide bir araya toplanması sadece Cuma ve Bayram günleri değil, köy hayrı gibi geniş katılımlı organizasyonlar da gerçekleştirilmektedir. Bu yönüyle de cami, köy toplumunda sosyal hayatın merkezi konumunda oldukça işlevsel bir fonksiyon üstlenmektedir.

\section{Cuma Pazarı Camisi}

Bursa Dă̆ Yöresinde geniş katılımlı Cuma namazının k1lındığg ve uygulamanın asırlardır devam ettiği camilerden en önemlisi kuşkusuz Büyükorhan İlçesi Cuma Pazarı Camisidir. Dağ Yöresinde sadece bu camiye ait geleneksel bir özellik de, sosyal yönden katılımın en yoğun olduğu bayram namazlarının eda edilmeyerek sadece Cuma namazlarının eda edilmesidir. Yani, Cuma Pazarı Camisi Cuma namazının kılındığı ama bayram namazlarının kılınmadığı tek cami özelliğine sahip bulunmaktadır.

Cuma camisinin, çok rağbet görmesinin sebebi caminin yörenin en büyük küçükbaş ve büyükbaş hayvan pazarının çevresinde kurulmasıdır. Bu pazarda alış-veriş için Bursa ve civar illere bağlı ilçelerden gelen esnaflara rastlamak mümkün olabilmektedir. Dolayısıyla gerek Büyükorhan'in köylerinden gerekse diğer ilçe ve köylerden birçok insan, cuma günleri Büyükorhan ilçesinin girişinde, ilçeye üç km. mesafede genişçe bir alanda yer alan caminin çevresinde toplanmaktadır. Özellikle yarım asır önce ekonominin tamamen tarım ve hayvancılığa dayalı olduğu bir dönemde, buradaki pazar yerinin ve hareketliliğin nedenli büyük olduğu tahmin edilebilir. Dağ Yöresi ve civarındaki yerleşim yerlerinde, inançların sosyal ve ekonomik hayatı düzenlemede nedenli güçlü olduğunu göstermesi bakımından Cuma Pazarı Camisi güzel bir örnektir. 
Cami çevresindeki mekânlarda hayvan satışının yanı sıra, uzun ve kapalı bir alanda da yeni kesilmiş hayvanların etleri ve bu etlerden mamul kavurmalar satılmaktaydı. Esnaflar sadece Cuma günü tezgâhlarını kurarak pazara gelenlerin et ve yemek ihtiyacını karşılamaktaydı. Eskiden tahıl başta olmak üzere her türlü ihtiyaç ürünlerinin alınıp satıldığı ve tam bir emtia pazarı örneği olarak nitelendirilebilecek olan bu mekânlar 1990'lı yıllara kadar bu özelliğini korumuştur. Bu y1llardan sonra pazarlama usullerindeki gelişmeler, tüketim alışkanlıklarının değişmesi, hayvancılık sektöründeki gelişme, çeşitli kurumların kesim için hayvan alımlarını doğrudan köylerde yapması gibi nedenlerle bu Cuma Pazarı ve dolayısıyla Cuma Pazarı Camisi de işlevini yitirmeye yüz tutmuştur. Günümüzde ilçe merkezinden, yerel ve mülkî yöneticiler dâhil olmak üzere birçok kişi, hayvan almayacak olsalar bile çeşitli bahanelerle gittikleri bu sosyal mekânları geleneksel olarak yaşatmaktadırlar.

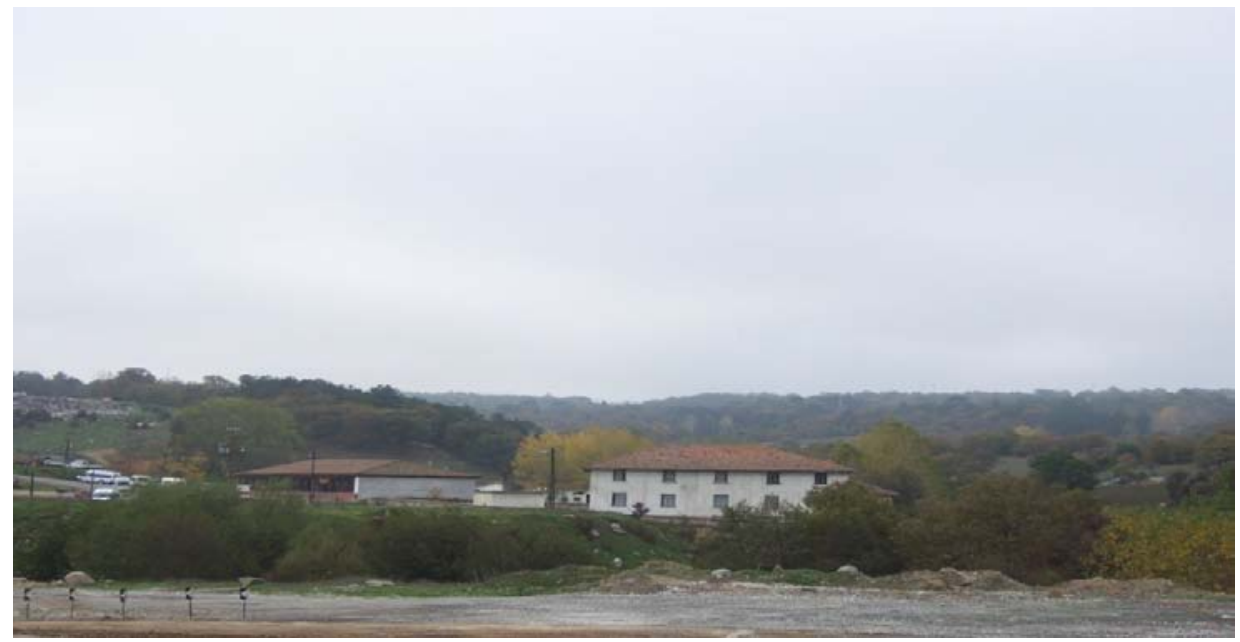

Cuma Pazarı Camii Ve Pazar Yeri/ Büyükorhan

Ekonomik, sosyal ve geleneksel boyutları olan böyle bir mekân için kaydedilmesi gereken önemli bir husus da; buraya yakın bir köy olan Armutçuk'ta mezarı bulunan, yöre halkının hürmetle andığı ve yaşadığı dönemin önemli bir din âlimi kabul ettiği Osman Efendi adıyla maruf zatın "Cuma Pazart" diye bilinen bu mekânın kurucusu olarak kabul edilmesidir. Yöre halkı bu kişiyi Osman Dede diye adlandırmaktadır. Burada yer alan camiyi onun yaptırdığı ve uzun süre burada imamet görevinde bulunduğu çeşitli efsane ve menkıbeler eşliğinde anlatılmaktadır. Yarı efsanevî bir şahsiyet olan Osman Efendi'ye ait bilgiler, yöreyle alakalı çok az sayıdaki son dönem yazılı kaynaklarda da geçmektedir. (Türkmen,1999-2000: 22-23) Bu durum son çeyrek asra gelene kadar toplum hayatının çeşitli alanlarında inançlar ve topluma inanç değerlerinin aktarılmasını sağlayan inanç ve kanaat önderleri, sosyal, kültürel ve ekonomi alanlarında belirleyici roller üstlenmişlerdir. 
Toplum bu tür kişiler tarafından önlerine konulan ve yararına olduğunu düşündüğü alanlarda onları takip etmiştir. Ayrıca bu duruma bakarak bir din âliminin tesir alanı dini konularla sınırlandırılmamış, sosyal hayatın bir çok boyutunda varlığııı hissettirmiştir denebilir.

\section{Kuruldukları Fiziki Mekânlara Göre Cuma Camileri}

Bursa Dağ Yöresi Cuma Camilerinin kuruldukları yerler ve mekânlar dikkate alınarak bir değerlendirme yapıldığında bu camilerin beli bir sosyal, ekonomik ve ulaşım özellikleri taşıyan yerlerde kurulduğu görülmektedir.

Cuma Yeri, Cuma Cami adlariyla maruf bu camilerin kuruldukları mekânlar şu unsurlar dikkate alınarak seçilmiştir:

a. Birden fazla köy ve mahallenin orta noktası bir alanda veya yakın yerlerde oturan kişilerin tamamının katılımını sağlayacak yer ve mekânlarda kurulan Cuma Camileri.

Yöredeki Cuma camileri daha çok bu amaca matuftur. Harmancık'a bağlı Çatalsöğüt, Dutluca ve İshaklar köyleri sınırları içinde bulunan Cuma camileri ile Keles ilçesi Kozağacı mevkiinde bulunan Cuma Yeri bu grupta değerlendirilebilir. $\mathrm{Bu}$ camiler, genellikle köyler topluluğunun ortasında bir yerde kurulmuş ve köylerden bağımsız olarak düşünülmüştür. Buralardaki Cuma Camilerinde cuma namazları civar köy ve mahalle sakinlerinin iştirakiyle geniş katılımlı bir şekilde eda edilmiş, bölgenin yakın köylerinin haftalık genel toplantıs1, görüşmesi ve kaynaşması için uygun bir zemin oluşturulmuştur. Böylece komşu köylerin ortak bir değer ve mekân etrafında toplanıp kaynaşması azami ölçüde sağlanmıştır.

Çatalsöğüt Köyü Doğancılar Mahallesi yakınlarında yer alan Cuma Camisinde Çatalsöğüt merkeziyle birlikte, Doğancılar, Demirci ve Bayramlar mahalleleriyle Kılavuzlar Köyü'nün Köçekler mahallesi sakinlerinin cuma namazlarını burada eda ettiği anlatılmaktadır. Yine Dutluca Köyü sınırlarında kalan Cuma Yeri ya da Cuma Camii'nde kılınan cuma namazlarına ise Ilıcaksu Köyü, Dutluca Köyü ve Koyak Mahallesi ile Dedebalı Köyü ve Gölcük Mahallesi'nden insanların katıldığı belirtilmektedir.

b. Köy ve mahallelerin katılımını sağlamaya yönelik olmakla birlikte, il ya da ilçeler arasındaki işlek yolların kenarında yapılarak yolcuların ibadetlerini de eda etmelerini sağlayacak tarzda düsünülen Cuma camileri.

Harmancık ilçesine bağlı Dedebalı, Ilıcaksu, Dutluca köylerinin orta noktas1 sayılabilecek bir mevkide yer alan Cuma Yeri aynı zamanda Harmancık-Dursunbey karayoluna yakın bir yerde inşa edilmiştir. Ancak ahşap olan bu caminin malzemeleri sökülerek başka bir yere taşınmıştır. Günümüzde bu Cuma Camisinin olduğu alan üzerinde, adı geçen köylerin katılımıla gerçekleşen ve her yıl düzenlenen köy hayrı yapılmaktadır. Harmancık Nalbant köyünde olan ve günümüzde de faaliyet halinde bulunan cami Harmancık-Keles ilçelerini birbirine bağlayan karayolunun kenarında bulunmaktadır. 
c. Insanların alışverişs yaptıkları yani ekonomik hareketliliğin yoğun olduğu mekânlara kurulan Cuma camileri.

Ekonomik hareketliliğin yoğun olduğu mekânlarda kurulan Cuma camilerinin en güzel örneği Büyükorhan Cuma Pazarı Camisi'dir. Bir dönem civar il ve ilçelerden gelen esnafların oluşturduğu ve yörenin en büyük hayvan pazarının kurulduğu yer olması nedeniyle, pazar yerinin yanına ekonomik hareketlilik göz önünde bulundurularak Büyükorhan Cuma Pazarı Camisi inşa edilmiştir.

\section{SONUÇ}

Cuma camisine bağlı uygulamalar, tarihi kökleri olan ve İslam'ın ilk dönemlerinden bu yana neredeyse Müslüman coğrafyasının tamamında varlığını sürdüren sosyal ve kültürel bir gelenek olmuştur. $\mathrm{Bu}$ gelenek günümüzde kısmen değişikliklere uğramakla birlikte, Türkiye'nin bazı yerlerinde içerik olarak halen varlığını sürdürmektedir. Araştırmanın konusu olan Bursa Dağ Yöresinde de var olan camiler bunların en güzel örnekleri olarak karşımıza çıkmaktadır.

$\mathrm{Bu}$ camilerde halen insanlar sosyal kaygilarla bir araya gelmektedirler. $\mathrm{Bu}$ bir araya gelmelerle sosyal ve kültürel anlamda toplumsal hayatın ayırt edici unsurlarını belirleyen, nesiller arası ortak kültürel değerlerin oluşumu ve aktarımı, geleneksel hayatın canlılığı ve sürekliliği sağlanmaktadır.

Özetle; Bursa Dă̆ Yöresi yerleşim birimindeki Cuma Camileri için, kuruldukları zaman itibariyle çevrelerindeki coğrafyalar için yerleşim önceliğini belirleyen yegâne etken ve mekânlar olduğu rahatlıkla söylenebilir. Dolayısıyla, sosyal hayat bu mabetler etrafinda gelişmekte ve şekillenmekte idi. Çünkü bu uygulamalar insanların belli aralıklarla bir araya gelmesi, dinî/dünyevî işlerini görmesi, merkezi otoritenin tarzını insanlara aktararak insanların hayatını yönlendirmek suretiyle, maddi ve kültürel alanlarda bir hayat tarzı oluşturmanın aracı olmuştur. Ayrıca, bu uygulama ile camiler, köylü/mahalleli fikri etrafinda toplanarak toplum içinde kaynaşmayı, gerektiğinde ortak kararlar almayı temin gibi sonuçlar sağlayan mekânlar olarak ciddi sosyal fonksiyonlar üstlenmektedir. Dahası bu mekânlar, İslam'ın ilk döneminden itibaren çeşitli coğrafyalarda kesintisiz olarak kendisine bir uygulama alanı bulan Müslümanların çok önem verdiği Cuma namazı ibadetinin ve onun etrafinda gelişen sosyal ve kültürel birikimlerin Müslüman toplumlarda gelenek olarak derinleşmesine ve günümüzde de devam etmesinin önemli mekânları olmaktadır.

Dağ Yöresindeki birçok Cuma Camisi işlevini yitirmiştir. Hâli hazırda faal durumda olan ve ssrarla bilinçli bir tercih olarak yaşatılan Harmancık ilçesi Nalbant Köyü’nde bulunan Cuma Cami ile Büyükorhan ilçesindeki Cuma Pazarl camileri yüzyıllardır devam eden Cuma Camisi geleneğinin günümüzdeki iki önemli tanığı olarak varlığını sürdürmektedir. Dağlık yörelerde bulunan yerleşim birimlerindeki genel kabullerin değişmesi, büyük 
illere yoğun göçün hâlâ yaşanıyor olması, Dağ Yöresindeki geleneksel uygulamaların hızlı bir şekilde yok olmaya doğru gitmesinin sebepleri olarak gösterilse de adı geçen iki camideki Cuma cami geleneğinin sürdürülmeye çalış1lyyor olması yerel kültürlerin hayatta kalma mücadelesi ve geleneklerin yaşatılabileceğinin bir göstergesi olarak düşünülebilir.

\section{KAYNAKLAR}

AĞIRMAN, Mustafa (2000), “Hz. Peygamber'in Mescidde Yaptı̆̆1 Sohbetler”, Atatürk Üniversitesi Illâhiyat Fakültesi Dergisi, sayı: 27, Erzurum, Say1 23.

AKMAYDALI, Hüdavendigâr (1994), Namazgahlar, Vakıflar Dergisi,

ARMAĞAN, Mustafa (1998), Bursa Şehrengizi, İz Yay. İst.

BAYARTAN, Mehmet (2005) "Osmanlı Şehrinde Bir İdari Birim: Mahalle”, İstanbul Üniversitesi Edebiyat Fakültesi Coğrafya Dergisi, Sayı: 13. 28042012

BİLİCI, Abdülhamit "Ciddi Gazeteye Ağır Sorular", Zaman Gazetesi,

CEMILOĞLU, Mustafa (2002), "Bursa Yöresi Mistik Folkloru Kapsamında Atalar Kültünden Yer-Su Kültüne Uzanan Bir Çizgi ve Saruhanlar Köyü Ebe Ana Yatırı Çevresindeki İnanç Oluşumu", Bursa Halk Kültürü, I. Bursa Halk Kültürü Sempozyumu (4-6 Nisan 2002) Bildiri Kitabl, c. II, UÜ. Rektörlüğü, Bursa

CEMILOĞLU, Mustafa (2002), Bursa Dă̆ Köylerinde Türkmen Kültürü, U.Ü. yayınları, Bursa

CEMiLOĞLU, Mustafa (2005), Bursa Bölgesi Yörükleri, Osmangazi ve Bursa Sempozyumu Bildiri Kitabı, (Edit. Cafer Çiftçi), Bursa Osmangazi Belediyesi Yay., Bursa.

DİKMEN, Alaattin ( 2011), Semaya Açık Namazgahlar, Bursa'nın Tarihi Mahalleleri II, Bursa Büyük Şehir Belediyesi Yay., Bursa

DİKMEN, Alaattin (2011), Gelenek ve İnançlarlyla Uludağ'ın Arka Yüzü, Bursa BB Yay, Bursa.

DİNÇEL, Ö. Faruk (2003), Yörük ve Türkmen Diyarı Bursa Dă̆ Yöresi, Dağ-Der yay., Bursa.

Doğuştan Günümüze Büyük İslam Tarihi, (1990), C.I, Çağ Yay., İst.,

ERGENÇ, Özer (1995), Osmanlı Klasik Dönemi Kent Tarihçiliğine Katkı XVI. Yüzyllda Ankara ve Konya, Ankara. İst.,

ERGIN, Osman Nuri, (1936), Türkiye'de Şehirciliğin Tarihi İnkişafi,

GÜMÜŞÇÜ, Osman (2002), Tarihi Coğrafya Açısından Bir Araştırma, XVI. Yüzyll Larende (Karaman) Kazasinda Nüfus ve Yerleşme, Ankara

GÜNER, Ahmed (1993), "Asr-l Saadette Mescidler/Camiler ve Fonksiyonları", Bütün Yönleriyle Asr-ı Saadette İslam, (Edt. Vecdi Akyüz), C.3, Beyan Yay., İst. 
İBN SA’D, Tabakat, Kahire 2001, I. 214.

İPŞİRLİ, Mehmed, "CumaSelamlığı”, TDV İslam Ansiklopedisi, , C.8, İstanbul.

İslam Ansiklopedisi, (1988), M.E.G..S.B., C.3, M.E.Basımevi, İst., İslam Ansiklopedisi, "Cami” maddesi, C.VII., TDV.

KUBAN, Doğan (1953), "Anadolu-Türk Şehri Tarihî Gelişmesi, Sosyal ve Fizikî Özellikleri Üzerinde Bazı Gelişmeler”, Vakıflar Dergisi, VII.

MERMUTLU, Bedri (2011), Kurtoğlu, Namazgah, Bursa'nın Tarihi Mahalleleri II, Bursa Büyük Şehir Belediyesi Yay., Bursa

ONAY, Ahmet (2007) “Türkiye'de Camilerin Gruplandırılması, Sınıflandırılması ve Görevli İhtiyaçlarının Belirlenmesine Yönelik Bir Çalışma”, Sakarya Üniversitesi Illahiyat Fakültesi Dergisi, Sayı: 16.,

ÖNKAL, Ahmed ve BOZKURT, Nebi (1993) “Cami” maddesi, TDV İslam Ansiklopedisi, , C.7, İst.

ÖZDEĞER, Hüseyin (1988), Onaltıncı Asırda Ayıntab Livası, İstanbul Üniversitesi yay., İstanbul

ŞAHINALP, Mehmet Sait (Ocak 2005), “Şanlıurfa Şehri'nin Kültürel Fonksiyonu”, Marmara Coğrafya Dergisi, Sayı: 11, İstanbul.

Taberî, Tarihu'1-Rusul ve'l Mulûk (thk. Muhammed Ebu'l-Fadl İbrahim), Misir 1968, II

TÜRKMEN, Serkan (2000), Halk Edebiyatı Büyükorhan Derleme, E.Ü.F.E.F. Türk Dili ve Edebiyat1 Bölümü Halk Edebiyat1 Dersi, Yayınlanmamış Bitirme Tezi.

ÜNVER, Zafer (2011), “Namazgahlar”, Bursa'nın Tarihi Mahalleleri II, Bursa Büyük Şehir Belediyesi Yay., Bursa.

WENSINEK, A.J., Mescit, İ. A. VIII, 673.

YEDIYILDIZ, Bahaeddin (1988), "1485-1576 Yilları Arasında Samsun Şehri”, I. Tarih Boyunca Karadeniz Kongresi (13-17 Ekim) Bildirileri, Samsun. 